\title{
Construction and Preservation of a Stable and Highly Expressed Recombinant Helicobacter pylori Vacuolating Cytotoxin A with Apoptotic Activity
}

\section{Ling-Zhi Yuan}

Central South University Third Xiangya Hospital

\section{Xiao Shi}

Central South University Third Xiangya Hospital

\section{Dan Tang}

Central South University Third Xiangya Hospital

\section{Shao-Peng Zheng}

Central South University Third Xiangya Hospital

\section{Zhi-Ming Xiao}

Central South University Third Xiangya Hospital

\section{Fen Wang ( $\nabla$ wfen-judy@csu.edu.cn )}

The Third Xiangya Hospital of Central South University https://orcid.org/0000-0002-1387-1126

\section{Research}

Keywords: Helicobacter pylori, VacA recombinant protein, expression, purification, preservation, apoptosis

Posted Date: October 23rd, 2020

DOl: https://doi.org/10.21203/rs.3.rs-94497/v1

License: (c) (i) This work is licensed under a Creative Commons Attribution 4.0 International License. Read Full License 


\section{Abstract}

Background: VacA is the only exocrine toxin of H. pylori, which plays a very important role in the customization of $\mathrm{H}$. pylori in the gastric mucosa, contributing to the pathogenesis of gastritis-cancer. Studies about vacA structure and function was hindered by the lack of efficient production system. In this study, we developed methodology for expression, purification and stable storage of a functionally active $\operatorname{vacA}$ toxin in E.coli.

Results: A 2502-bp fragment and vacA gene were identified. An 89.7-kDa VacA ${ }^{34-854}$ recombinant protein was expressed and purified from the recombinant engineering bacteria and was preserved stably in 50 $\mathrm{mM}$ acetic acid buffer $(\mathrm{pH}$ 2.9). The amount of the recombinant protein was larger in the inclusion bodies than in the supernatant. In addition, after a 24-h culture with VacA recombinant protein, GES-1 cells demonstrated evidence of apoptosis including early nuclear immobilization and clustering under inverted microscope and TEM. It was found that VacA recombinant protein induced apoptosis by TUNEL assay.

Conclusions: A VacA recombinant protein that is stably and highly expressed and possesses proapoptotic activity is successfully constructed. The protein is stably preserved in $50 \mathrm{mM}$ acetic acid buffer $(\mathrm{pH} 2.9)$.

\section{Key Points}

Our study provides a novel method for the preparation, renaturation and stabilization of a functionally active recombinant VacA. The protein is stably preserved in $50 \mathrm{mM}$ acetic acid buffer $(\mathrm{pH}$ 2.9), the low pH environment is in accordance with the gastric pathogenic conditions in the physiological status of $\mathrm{H}$. pylori, which is more conducive to studying the mechanism of $\mathrm{H}$. pylori in the stomach. The traditional process of acidic activation of VacA recombinant proteins at low $\mathrm{pH}$ was eliminated in the present study, so the protein can be used directly.

\section{Background}

Helicobacter pylori, a main pathogen in the stomach, is closely associated with chronic gastritis, peptic ulcer disease, mucosa-associated lymphoid tissue lymphoma, and gastric cancer [1]. In 1994, the International Agency for Research on Cancer (IARC) officially listed H. pylori as a class I carcinogen for gastric cancer [2]. H. pylori infection is considered to be the most common infection worldwide with more than $50 \%$ of the world's adult population being infected with the bacterium [3]. The prevalence of $H$. pylori is up to $90 \%$ in developing countries, while the annual recurrence rate is much higher than that in developed countries [4]. Persistent $H$. pylori infection, especially with a cytotoxic strain, leads to chronic gastric inflammation, tissue damage, increased cell proliferation and apoptosis, subsequent to precancerous lesions including atrophy, intestinal metaplasia, dysplasia, and finally gastric cancer [5].

One of the most crucial toxins produced by H. pylori is the vacuolating cytotoxin A (VacA), which has been demonstrated to play a vital role in the pathogenesis of peptic ulcer disease and gastric cancer [6, 
7]. As a key toxin for $H$. pylori pathogenesis, VacA exerts a variety effects on target cells, including the induction of "vacuole"-like membrane vesicles in the cytoplasm of gastric cells, disruption of mitochondrial functions, stimulation of apoptosis and blockade of T-cell proliferation [3]. VacA is also important for colonization of $H$. pylori in vivo. Given the fascinating multi-functionality of $V a c A$ and its association with an augmented gastric cancer risk, extensive investigation into the structure and function of $V a c A$ is essential to fully understand the pathogenicity of $V a c A$ and to identify diagnostic and therapeutic strategies accordingly. However, the investigation has been hindered, to some extent, by the lack of a highly efficient method for the production of $\operatorname{VacA}$. Several previous studies have reported that it is difficult to purify VacA from H. pylori and that the amount of protein that is produced is low [8]. Moreover, several recent studies have explored techniques through which to obtain a high-efficiency expression of VacA recombinant protein with biological-activity $[9,10]$. However, these studies have weaknesses and limitations in that small fragments of VacA protein cannot fully reflect the function of the VacA protein and that these VacA recombinant protein preparations need to be acid-activated prior to use $[11,12]$. Therefore, the aim of the present study was to establish a technique through which to construct and preserve a stable and highly expressed VacA recombinant protein that possesses the biological activity of promoting apoptosis.

\section{Results}

\section{Construction of recombinant VacA-expressing plasmid}

A VacA-expressing plasmid was constructed successfully. Figure 1a shows that a single band, with a size of approximately $2502 \mathrm{bp}$, was generated from the recombinant plasmid. This finding is basically consistent with the expected fragment size. Ndel \& Xhol endonuclease analysis of the recombinant plasmid revealed two corresponding electrophoretic bands, which were consistent with the sizes of the pET-41b plasmid linear vector (5932 bp) and the target VacA gene fragment (2502 bp; Fig. 1b). The sequencing of the recombinant plasmid revealed that the target gene fragment was completely consistent with the corresponding sequence of the vacA fragment in GenBank (Fig. 1c \& Supplementary Fig. S1). This suggests that it was a specific target PCR product and that the recombinant plasmid was successfully constructed.

\section{Expression and purification of VacA recombinant protein}

IPTG at the concentration of $0.5 \mathrm{mM}$ at $15^{\circ} \mathrm{C}$ for $16 \mathrm{~h}$ efficiently induced the expression of the VacA recombinant protein in the $p E T-41 b-v a c A^{34-854}-E$. coli BL21(DE3) system (Figs. 2a \& 2b). We attempted to further purify the target protein from the supernatant and inclusion bodies, respectively, and found that a small amount of protein was present in the supernatant (Figs. 2c \& $2 \mathrm{~d}$ ) and a large amount of protein was present in the pellet (Figs. 2e). 


\section{Refolding, preservation and identification of VacA recombinant protein}

A variety of protein refolding methods were attempted (Fig. 3a). In the one-step dialysis method, buffers 1-5 and 7 were all unsuccessful while the protein was recovered successfully in buffer 6 (Fig. 3a). However, Arg, which has an effect of promoting apoptosis, is present in buffer 6 . The presence of Arg would, thus, interfere with the detection of the pro-apoptotic biological activity of the target VacA protein. Because of this, buffer 6 was not considered to be suitable as the final protein solution. Therefore, we chose the two-step dialysis method for purification from inclusion bodies, and the target protein was successfully dissolved in $50 \mathrm{mM}$ acetic acid buffer (pH 2.9; Fig. 3b). Finally, an 89.7-kDa VacA recombinant protein molecular weight was obtained in the supernatant (Figs. 4a \& 4b) and, in a larger amount, in the pellet (Figs. 4c \& 4d).

\section{Apoptotic activity of VacA recombinant protein}

Significant apoptotic activity was observed at a final concentration $(65 \mu \mathrm{g} / \mathrm{mL})$ for $24 \mathrm{~h}$. Under invert microscope and transmission electron microscope, significant cell morphological changes evident of apoptosis including early nuclear immobilization and clustering in GES-1 cells were observed. A large number of nuclei were retracted and chromatin in the nucleus converged to the edge, and the apoptotic activity appeared to be time-dependent (Figs. 5 \& 6). In addition, a significant increase of apoptosis was observed as compared to the buffer control group using TUNEL (Fig. 7, P $<0.01$ ) assays. No obvious cell vacuolation was observed with the two concentrations at any of the time points (Figs. $5 \& 6$ ).

\section{Discussion}

In the present study, a VacA recombinant protein was successfully produced by a recombinant plasmid (pET41b-VacA ${ }^{34-854}$ ) in E. coli BL21(DE3). In addition, the purified VacA recombinant protein in the inclusion bodies was preserved stably in acetate buffer ( $\mathrm{pH} 2.9)$ with the biological activity of promoting apoptosis. Therefore, this recombinant VacA can be used as VacA toxin to directly perform H. pylorirelated basic research, providing a tool for further study of $H$. pylori virulence factor VacA pathogenic mechanism.

In contrast to the endogenous expression of the vacA toxin gene in cells, we chose to construct the VacA recombinant protein for subsequent basic experiments. In a previous study, our team screened the vacAs $1 \mathrm{~m} 1 \mathrm{H}$. pylori clinical strain, a highly virulent strain that is associated with atrophic gastritis, as demonstrated by animal infection models [13]. To further explore the mechanism of VacA toxin in $H$. pylori-related gastric precancerous lesions, a VacA eukaryotic expression plasmid was constructed and transfected into GES-1 cells (human gastric mucosal epithelial immortalized cells). We found that apoptosis and cell vacuolation were not obvious in this model. The main reason for this phenomenon is that there is a contact effect between H. pylori and epithelial cells in the host, and, thus, the endogenous expression of the vacA gene in the cell, induced by plasmid transfection technology, does not fully reflect 
the toxin effect of VacA. de Bernard et al. [14] reported that both microinjection of VacA in HeLa cells and transfection with plasmids encoding VacA in HeLa cells caused the formation of vacuoles. A recent study [15] showed that $V a c A$ is the only exocrine toxin that is secreted from H. pylori, and plays a crucial role through the manipulation of the type II secretion system in target cells. RPTPa/RPTP $\beta$ and LRP1 have been identified as cell-surface VacA-binding receptors. These receptors contribute to the internalization of VacA into epithelial cells, as well as activating signal transduction pathways, cell death and gastric ulceration. The interaction between $V a c A$ and target cells is the crucial event in the induction of the toxicity. Hence, the application of ectogenic VacA toxin on target cells would provide an improved simulation of the toxic effects of $H$. pylori on epithelial cells in the physiological state.

We successfully obtained a VacA recombinant proteins from the pET41b-VacA ${ }^{34-854}-E$. coli BL21(DE3) expression system. Three sources of the VacA toxin have been reported in recent studies: 1) the concentrates of supernatants from $H$. pylori liquid culture was used as rough $\operatorname{VacA}[16,17], 2)$ filtration and purification of the natural VacA protein [18] 3) production of a VacA recombinant protein $[19,20]$. Each of these sources has advantages and disadvantages. The crude $H$. pylori supernatant concentrate has the ability to maintain the intrinsic antigenicity and biological activity of the VacA protein and the method is relatively simple. However, it is difficult to explain and analyze the function of the protein because of the complicated composition. The procedure of filtration and purification of native the VacA protein is complex. Hence, much effort needs to be taken, including culturing massive H. pylori cells and collecting the bacteria or supernatant. After the multi-step purification, only a small amount of the target protein is obtained. For production of a VacA recombinant protein, the full-length or fragment of VacA genes are amplified and the genetic transformation technique is used to construct an expression vector carrying the target genes. Then, the target genes of the VacA toxin are transformed into E.coli and the directional expression of E.coli is induced to secrete the VacA protein. Preparation of the VacA recombinant protein is relatively simple and large amount of protein can be produced, which may be sufficient for studying the pathogenic mechanism of $H$. pylori. In addition, the available data indicate that the antigenic region and antigenic property of the recombinant VacA protein are similar to those of the native VacA antigen, which can be further used for the development of $H$. pylori vaccine and diagnostic kits [21].

In our study, mature fragments of the VacA protein from $\mathrm{H}$. pylori strain were amplified, yielding an 89.7$\mathrm{kDa}$ VacA recombinant protein, $\mathrm{VacA} \mathrm{A}^{34-854}$. The vacA gene encodes a protoxin, approximately $140 \mathrm{kDa}$ in mass. Both the amino-terminal and carboxy-terminal signal sequence are proteolytically cleaved during the process of $V a c A$ secretion, and a $₫ 90 \mathrm{kDa}$ mature toxin is exported [22]. Mature toxin molecules are released into the extracellular space and the amino-terminal signal sequence is firstly cleaved. Then, a $88 \mathrm{kDa}$ secreted toxin can be further hydrolyzed and processed into two different domains, which have different functions [22]: an N-terminal fragment of $33 \mathrm{kDa}$ (p99, residues 33-311, toxin activity subunit) and a C-terminal fragment of $55 \mathrm{kDa}$ (p55, residues 312-821, binding subunit) [23]. Chang et al. [24] amplified the full-length $V a c A$ genes in order to construct a VacA protoxin. They found that the recombinant VacA toxin lost the epithelial apoptosis promoting activity. This indicates that the spatial 
configuration of the macromolecular protein is influenced by the expression of full- length VacA genes in E.coli. Therefore, the intrinsic bioactivity of the native toxin could not be seen. Almost all H. pylori strains show allelic variations in the three regions of the vacA gene: $s$ region, i region and $m$ region [25]. The combination of two different alleles in each region induces the intensity of vacuolar-like changes in gastric epithelial cells [26] and the H. pylori strain that produces the VacA protein with a molecular weight of $88 \mathrm{KDa}$ is more virulent. In the present study, we analyzed nucleotide sequences of multiple variants of vacA gene that are published in GenBank and found that 5 ' terminal sequences show a high homology. Hence, the VacA mature stable protein fragment from H. pylori standard strain $\mathrm{J} 99$ was amplified, and the VacA recombinant protein with molecular weight of $89.7 \mathrm{kDa}$ was successfully obtained.

In the present study, a larger amount of VacA recombinant protein was purified from inclusion bodies than the supernatant in E.coli and this protein had a pro-apoptotic biological activity. Previously, several studies have reported on the preparation of the VacA recombinant protein; however, there is no consensus on the bioactivity of the recombinant VacA protein. Cho et al. [27] applied a DNA amplification technique to construct recombinant the VacA protein p58 fragment, namely VacA ${ }^{418-799}$. A recombinant protein, $\operatorname{VacA}{ }^{418-799}$, with a molecular mass of $45 \mathrm{kD}$ a was purified from the inclusion bodies. This protein inhibited cell growth in gastric carcinoma cells and induced apoptosis in a dose-dependent and cyclindependent manner. Manetti et al. [28] used gene transformation technology to induce the expression of the VacA toxin secreted from in E.coli. Although the 95-kDa VacA polypeptide was abundantly expressed, it completely lacked any biological activity. Gonzalez-Rivera et al. [10] found that both the p33 domain and p55 domain (residues 346 and 347) were required for assembly of VacA in the oligomeric structures, and that proteins lacking these sequences fail to cause cell vacuolation. Junaid et al. [9] constructed mature fragment of the VacA protein and showed that the VacA toxin was able to induce apoptosis in both human colonic adenocarcinoma cells and Madin-Darby canine kidney epithelial cells. We were able to purify the VacA toxin from the supernatant and inclusion bodies, with a larger amount of target protein being obtained from the inclusion bodies than from the supernatant. Generally, when many exogenous proteins are expressed in E.coli, they cannot spontaneously fold to produce proteins with certain spatial structures and specific biological functions. Hence, they exist intracellularly, lack biological activities, and are not able to be applied directly. If the inclusion bodies are renaturated, protein folding will recover the biological activities $[29,30]$. There are various reports on the recovery and preservation of the VacA recombinant protein. In the present study, several methods that have been reported in previous studies were attempted $[8,10,31-32]$ to induce VacA protein renaturation. However, none of these techniques were able to preserve the proteins stably. Successful protein renaturing was observed following incubation in buffer 6 ( $20 \mathrm{mM}$ Tris, $2 \mathrm{M}$ urea, $400 \mathrm{mM}$ Arg, $2.5 \mathrm{mM}$ cysteamine, $0.25 \mathrm{mM}$ cystamine, $\mathrm{pH}$ 8.5). However, this buffer contained Arg, which has a promoting effect on apoptosis [33]. Thus, the Arg in buffer 6 would interfere with the detection of the pro-apoptosis biological activity of the VacA protein, and its use in the preservation of VacA protein should be avoided if the protein is to be tested for its biological activities. It has been demonstrated that acidic solution is beneficial for the colonization of $H$. pylori, as well as the activation and maintenance of VacA toxin biological activities [11]. The specific activities of the core position of $\mathrm{VacA}$ are triggered following exposure to low $\mathrm{pH}$, which significantly maintains the 
spatial conformation of the VacA protein [12] [34]. Thus, we finally chose a two-step dialysis method: i.e. the protein was successfully dissolved in buffer 6 , and then dialyzed into buffer 7 ( $50 \mathrm{mM}$ acetic acid, $\mathrm{pH}$ 2.9). In the present study, the VacA recombinant protein was successfully renatured, dissolved in buffer 6 and stably stored in buffer 7 . This protocol is in accordance with the gastric pathogenic conditions in the physiological status of $H$. pylori [35]. It should be mentioned that the traditional process of acidic activation of recombinant proteins at low $\mathrm{pH}[11]$ was eliminated in the present study.

The VacA recombinant protein obtained by different methods usually has differences in concentration, purity and protein preservation solution. Therefore, the specific amount of the VacA protein used in the experimental study is not uniform. In our study, we started with concentration $5 \mathrm{ug} / \mathrm{ml}$, gradually increased the protein concentration, incubated VacA protein with different concentrations and gradients and observed that cell morphological changes at each time point. It was found that apoptosis could be changed after the protein was incubated for a long time with a low concentration or stimulated for a short time with a high concentration, and the effect of high concentration was more significant. Finally, the protein was selected to stimulate cells with a higher concentration of $65 \mathrm{ug} / \mathrm{ml}$ to test the pro-apoptotic biological activity of the protein and conduct subsequent experiments. The VacA recombinant protein that was preserved in acetic acid buffer was applied to GES-1 cells and was found to promote apoptosis. However, the promotion of vacuolation was not obvious. This is likely due to the influence of several factors, including the H. pylori strain, cell strain, incubation time, temperature [24], $\mathrm{pH}$ [36] and $\mathrm{Y}^{-}$ glutamyltranspeptidase [37]. Thus, further investigation using different $H$. pylori strains, cell lines, incubation times and temperatures is needed.

$\operatorname{VacA}$ is one of the most important pathogenic factors of $H$. pylori and is attributable to strain-specific variations in toxin activity. It plays an important role in H. pylori-related gastric "phlogistic - carcinoma" lesions [7]. The immuno-inflammation effects of $V a c A$ on epithelial cells are complex, including the promotion of target cell membrane perforation [38], cytoplasmic vacuolation [39], apoptosis induction [40], and the regulation of the immune response by interfering with the signal pathway of $\mathrm{T}$ cell proliferation [41]. However, the specific mechanisms of the cytopathy and dysfunction that are caused by VacA toxin remain unclear. The ability to obtain a large number of biologically active VacA recombinant proteins will provide a direct tool for the study of VacA pathogenesis. Consequently, our study provides a novel method for the preparation, renaturation and stabilization of the VacA recombinant protein and lays a foundation for further exploration into the related disease processes, the pathogenesis of gastric mucosal injury and the occurrence of gastric cancer caused by $H$. pylori virulence factor, VacA. This bioactive VacA recombinant protein can be directly applied to gastric epithelial cells to study the dysfunction of "cytoinflammatory injury-proliferation repair" and abnormal immune regulation caused by H. pylori infection in further research.

\section{Conclusion}

In this study, an 89.7-kDa VacA recombinant protein was successfully constructed in E.coli, purified in large quantities from the inclusion bodies, and stably preserved in acetate buffer, $\mathrm{pH}$ 2.9. In addition, the 
produced VacA recombinant protein has the biological activity of promoting apoptosis. Our study provides a novel method for the preparation, renaturation and stabilization of a functionally active recombinant VacA. The protein is stably preserved in $50 \mathrm{mM}$ acetic acid buffer $(\mathrm{pH} 2.9)$, the low $\mathrm{pH}$ environment is in accordance with the gastric pathogenic conditions in the physiological status of $\mathrm{H}$. pylori, which is more conducive to studying the mechanism of $\mathrm{H}$. pylori in the stomach. The traditional process of acidic activation of VacA recombinant proteins at low $\mathrm{pH}$ was eliminated in the present study, so the protein can be used directly.

\section{Methods}

\section{Cell strain, bacterial strain and plasmids}

A human normal gastric epithelial cell line, GES-1, and a H. pylori reference strain (J99/ATCC 700824) were provided by the Cancer Research Institute of Central South University, Changsha, China. Escherichia coli strain, TOP10, was purchased from Genscript Biotech (Nanjing) Corp Co., Ltd, Nanjing, China, and E. coli BL21(DE3) strain and plasmid $p E T 41 b$ were purchased from Novagen Company, Madison, USA.

\section{Construction of a VacA recombinant expressing vector}

Genomic DNA of H. pylori was extracted according to the standard protocol for MiniBEST Bacterial Genomic DNA Extraction Kit (Takara Biotechnology Co., Ltd). The vacA gene of H. pylori (strain J99 / ATCC 700824) was amplified from the sequences (mature protein fragment of VacA toxin, expressing amino acids 34 to 858 ) by polymerase chain reaction (PCR) method using the mutation primers and gene primers (sequence $\mathrm{F} 1$ :

5'CAATCGTTGGCGGCATCGCTACGGGTACGGCTGTTGGCACGGTTTCGGGCCTGCTTAGTTGGGGACTC3', sequence $\mathrm{F}$ :

5'CTTTAAGAAGGAGATATACATATGTTTTTCACCACGGTTATCATTCCGGCAATCGTTGGCGGCATCGCT3'); F1 contained Ndel sites, and F contained Xhol sites. Conditions were as follows: Pre-denaturation at $96{ }^{\circ} \mathrm{C}$ for $5 \mathrm{~min}$; and $25 \mathrm{cycles}$ of $96^{\circ} \mathrm{C}$ for $30 \mathrm{sec}, 57^{\circ} \mathrm{C}$ for $30 \mathrm{sec}, 72{ }^{\circ} \mathrm{C}$ for $1 \mathrm{~min} 20 \mathrm{sec}$ and $72{ }^{\circ} \mathrm{C}$ for $5 \mathrm{~min}$. The PCR product was digested with $\mathrm{Ndel}$ and $\mathrm{XhOl}$, and inserted into the expression vector plasmid pET41b containing C-terminal histidine tag (8His.tag; Novagen Company). The PCR product and the inserted $p E T 41 b$ plasmid were then combined at a 10: 1 molar ratio in a ligation reaction containing $1 \times$ ligation buffer (50 mM Tris-HCl, pH 7.5, 10 mM MgCl2, 1 mM ATP, 1 mM DL-dithiothreitol (DTT), 25\% $(\mathrm{w} / \mathrm{v})$ polyethylene glycol 8000 ) with five units of T4 DNA ligase (Gibco BRL, USA) to reach a final volume of $20 \mu \mathrm{L}$ and incubated overnight at $16^{\circ} \mathrm{C}$. The combination product $(10 \mu \mathrm{L}, 300 \mathrm{ng})$ was mixed with competent cells $\left(100 \mu \mathrm{L}, 1 \times 10^{8} \mathrm{cfu} / \mu \mathrm{g}\right.$, the optical density of the cells at $600 \mathrm{~nm}$ reached $\left.0.5-0.8\right)$ of E.coli TOP10 on ice for $30 \mathrm{~min}$, in heat shock at $42^{\circ} \mathrm{C}$ for $60 \mathrm{~s}$, and then instantly incubated in an ice bath for $2 \mathrm{~min}$. The solution was grown in $800 \mu \mathrm{L}$ Luria-Bertani (LB) medium, preheated to room temperature, on a shaking incubator for $1.5 \mathrm{~h}$ at $37^{\circ} \mathrm{C}$. Afterwards, the cells were harvested by centrifugation at $13,523 \mathrm{~g}$ for $2 \mathrm{~min}$ and removal of $200 \mu \mathrm{L}$ supernatant. The solution was resuspended with $200 \mu \mathrm{L} \mathrm{LB}$ medium containing $50 \mu \mathrm{g} / \mathrm{mL}$ kanamycin and then the LB medium was evenly spread into a solid LB 
medium plate. Following this, the plate was reversely placed and cultured at $37^{\circ} \mathrm{C}$ overnight. Five wellgrown colonies on the solid LB medium plate were selected and inoculated into $5 \mathrm{~mL}$ LB medium containing $50 \mu \mathrm{g} / \mathrm{mL}$ kanamycin. Transformants were grown at $37^{\circ} \mathrm{C}$ overnight with shaking. Plasmids were extracted by the methods described by Green et al. [42]. Afterwards, the plasmids were digested with Ndel and Xhol. The restricted product, a 2502-bp positive clone, was assessed by $1 \%$ agarose gel electrophoresis. The correct recombinant clones were then validated by Sanger dideoxy sequencing, with the Applied Biosystems 3730XL DNA Analyzer (Thermo Fisher Scientific, Inc., Waltham, MA, USA).

\section{Expression and purification of VacA recombinant protein}

\section{Expression of VacA recombinant protein}

Recombinant plasmid containing the vacA insert ( $p E T 41 b$-vacA ${ }^{34-854}$ ) was transformed into $E$. coli BL21(DE3) (Novagen Company). Briefly, E. colicells were incubated in $4 \mathrm{~mL}$ LB medium containing $50 \mu \mathrm{g} / \mathrm{mL}$ kanamycin, and incubated overnight at $37^{\circ} \mathrm{C}$ with shaking at $225 \mathrm{~g}$. Then, the $4-\mathrm{mL}$ pre-culture above was seeded into $10 \times 500 \mathrm{~mL}$ Terrific Broth containing $50 \mu \mathrm{g} / \mathrm{mL}$ kanamycin in Erlenmeyer flasks, and incubated at $37^{\circ} \mathrm{C}$ with shaking at $225 \mathrm{~g}$. When the OD600 value of the culture reached 1.2, IPTG was introduced at the final concentration of $0.5 \mathrm{mM}$ into the culture to induce the protein expression at $15^{\circ} \mathrm{C}$ for $16 \mathrm{~h}$ with shaking at $225 \mathrm{~g}$. The cell pellet was harvested at $8,000 \mathrm{~g}$, maintained at $4{ }^{\circ} \mathrm{C}$ for 20 min. Following this, sodium dodecyl sulfate polyacrylamide gel electrophoresis (SDS-PAGE) and western blotting analysis were used to detect the VacA protein in E.coli expression in construct pET41b.

Purification of VacA recombinant protein: The cell pellet was harvested at $8,000 \mathrm{~g}$, at $4{ }^{\circ} \mathrm{C}$ for $20 \mathrm{~min}$, and re-suspended with the lysis buffer ( $50 \mathrm{mM}$ Tris- $\mathrm{HCl}, 150 \mathrm{mM} \mathrm{NaCl}, \mathrm{pH} 8.0)$. The cells were lysed using a sonicator (protocol: $3 \mathrm{sec}$ on and $6 \mathrm{sec}$ off cycles for a total of $15 \mathrm{~min}$ at $500 \mathrm{w}$ ) and the cell lysate was centrifuged at $14,650 \mathrm{~g}$, at $4{ }^{\circ} \mathrm{C}$ for $30 \mathrm{~min}$. The supernatant and inclusion bodies were separately collected for the purification of the VacA recombinant protein as described below.

\section{Purification of VacA recombinant protein from the supernatant}

The target protein was purified from the supernatant with Ni-IDA (Ni-IDA resin, Genscript Biotech (Nanjing) Corp Co., Ltd). The above-mentioned lysis buffer (50 mM Tris-HCl, $150 \mathrm{mM} \mathrm{NaCl}, \mathrm{pH} 8.0$ ) was used as the column equilibration buffer. The target protein was eluted with a stepwise gradient of imidazole $(50 \mathrm{mM}$ Tris $-\mathrm{HCl}, 150 \mathrm{mM} \mathrm{NaCl}, \mathrm{pH} 8.0+$ a gradient concentration of imidazole, i.e. 20, 50, 100 and $500 \mathrm{mM}$ ) and then washed with washing buffer (50 mM Tris, $150 \mathrm{mM} \mathrm{NaCl}, 1 \%$ TritonX-114, pH 8.0. The 1\% TritonX-114 acts to remove the endotoxin). Western blotting and SDS-PAGE were used to analyze the purification process. According to the results of Western blotting and SDS-PAGE, the target proteins in the lane with the most protein expression were pooled and dialyzed into buffer $1 \times \mathrm{PBS}, \mathrm{pH}$ 7.4. The dialysis was performed in a $14 \mathrm{kDa}$ cut-off dialysis membrane (VISKASE® Companies, Inc.) for $4 \mathrm{~h}$ and the above buffer was replaced with the same fresh buffer $(1 \times \mathrm{PBS}, \mathrm{pH} 7.4)$ for an additional $16 \mathrm{~h}$. After dialysis, the sample was centrifuged at 14,650 $\mathrm{g}$ for $30 \mathrm{~min}$ and filtered through a $0.22 \mu \mathrm{m}$ filter (Merck Millipore). The final quality control (QC) included SDS-PAGE along with western blotting. 


\section{Purification of VacA recombinant protein from inclusion body}

For the purification of VacA recombinant protein in the inclusion bodies, the inclusion body pellet was solubilized in the denature buffer $(50 \mathrm{mM}$ Tris- $\mathrm{HCl}, 7 \mathrm{M}$ guanidine hydrochloride, $\mathrm{pH}$ 8.0) by sonication. The cell precipitate was centrifuged at $14,650 \mathrm{~g}$ for $30 \mathrm{~min}$ at $4{ }^{\circ} \mathrm{C}$, and the supernatant was used for further purification. Ni-NTA (Profinity IMAC Ni-Charged Resin, Bio-Rad Laboratories, Inc.) affinity chromatography was applied to collect the recombinant protein in the supernatant. The above-mentioned denature buffer was used as the column equilibration buffer, and the target protein was eluted with a stepwise gradient of imidazole $(50 \mathrm{mM}$ Tris- $\mathrm{HCl}, 8 \mathrm{M}$ urea, $\mathrm{pH} 8.0$ + a gradient concentration imidazole, i.e. 20, $300 \mathrm{mM}$ ) after being washed with washing buffer (50 mM Tris-HCl, 1\% Triton-X114, $8 \mathrm{M}$ urea, $150 \mathrm{mM} \mathrm{NaCl}, \mathrm{PH}$ 8.0). SDS-PAGE was used to analyze the fractions in the purification process.

\section{Refolding, preservation and identification of VacA recombinant protein}

\section{Refolding and preservation of VacA recombinant protein}

The target protein eluted in the above inclusion body purification was pooled, and a small-scale refolding test was performed using the following refolding buffers and methods.

One-step dialysis method: buffer 1: $50 \mathrm{mM}$ Tris-HCL, 10\% Gly, $150 \mathrm{mM} \mathrm{NaCl}, \mathrm{pH}$ 8; buffer 2: $50 \mathrm{mM}$ TrisHCL, $10 \%$ Gly, $150 \mathrm{mM} \mathrm{NaCl}, 0.1 \mathrm{mM}$ DTT, pH 8.0; buffer 3: $1 \times$ PBS pH 7.4; buffer 4: $1 \times$ PBS, $10 \%$ GLy, $500 \mathrm{mM} \mathrm{NaCl}$, pH 7.4; buffer 5: 1 × PBS, 10\% GLy, 500 mM NaCl, 0.1 mM DTT, pH 7.4; buffer 6: $20 \mathrm{mM}$ Tris-HCL, 2 M urea, $400 \mathrm{mM}$ Arg, $2.5 \mathrm{mM}$ cysteamine, $0.25 \mathrm{mM}$ cystamine, pH 8.5; buffer 7: $50 \mathrm{mM}$ acetic acid, $\mathrm{pH} 2.9$.

\section{Two-step dialysis method}

Firstly, the protein was dialyzed to buffer 6 , and then to buffer 7 . Analysis of protein refolding was based on the protein solubility (when the protein was dissolved in the buffer, the appearance of the visible precipitate indicated refolding failure, whereas the complete dissolution indicated successful refolding) and SDS-PAGE results (the lysate was collected and the protein content was further analyzed by SDSPAGE). The dialysis was performed in $14 \mathrm{kDa}$ cut-off dialysis membrane for $4 \mathrm{~h}$ and for additional $16 \mathrm{~h}$ after replacement of the fresh buffer (i.e. the corresponding dialysis buffer in the one-step dialysis method, and buffer 6 in the two-step dialysis method). Then, dialysis was performed in the final buffer (i.e. the corresponding dialysis buffer in the one-step dialysis method, and buffer 7 in the two-step dialysis method) for $16 \mathrm{~h}$. The most suitable protein final solution was selected based on protein refolding results as well as the buffer solvent used in the solution, which must not interfere with the biological activity detection of the target protein.

\section{Identification of VacA recombinant protein}


After dialysis, the sample was centrifuged at $14,650 \mathrm{~g}$ for $30 \mathrm{~min}$ and filtered through a $0.22 \mu \mathrm{m}$ filter. The final QC included SDS-PAGE along with western blotting.

SDS-PAGE analysis: The protein sample was added to the loading buffer (300 mM Tris- $\mathrm{HCl}, 10 \% \mathrm{SDS}$, $30 \%$ glycerol, $0.05 \%$ bromophenol blue, $250 \mathrm{mM}$ DTT, $\mathrm{pH} 6.8$ ). The mixture was vortexed for $1 \mathrm{~min}$, heated at $100{ }^{\circ} \mathrm{C}$ for $10 \mathrm{~min}$, and centrifuged at $11,270 \mathrm{~g}$ for $1 \mathrm{~min}$. The supernatant was taken for SDS-PAGE analysis (Gel: 4\% 20\% gradient SDS-PAGE gel, Genscript Biotech (Nanjing) Corp Co., Ltd). Equal amounts $(2 \mu \mathrm{g})$ of bovine serum albumin, (BSA, $67 \mathrm{kDa})$ and the protein were added to the loading buffer. The next steps were performed as described above. After the electrophoresis was completed, the band of the target protein was compared with the band of the reference protein (BSA), and the amount of the target protein was initially obtained. PAGE-MASTER Protein Standard (Genscript Biotech (Nanjing) Corp Co., Ltd) was used as a protein molecular weight marker.

Western blotting analysis: After SDS-PAGE, the precast gel (4\% 20\% gradient SDS-PAGE gel, Genscript Biotech (Nanjing) Corp Co., Ltd) was fixed on electrophoretic apparatus and the inside of the electrophoresis tank was topped up with MOPS electrophoresis buffer. Then, the protein samples were added into the gel holes. Easy Western Protein Standard (Genscript Biotech (Nanjing) Corp Co., Ltd) was used as a protein molecular weight marker. SDS-PAGE was run at $140 \mathrm{~V}$ for $60 \mathrm{~min}$, and stopped when the bromophenol blue reached the bottom of the separation gel. The gel was removed, and transferred onto the PVDF membrane (Bio-Rad Laboratories, Inc.) by using e-blot (a highly efficient wet protein transfer system). The membrane was washed with $1 \times$ PBST $(1 \times$ phosphate buffered saline (PBS), $0.06 \%$ Tween-20, pH 7.4) buffer twice, for 5 min each time, removed and sealed with rapid sealing liquid (Genscript Biotech (Nanjing) Corp Co., Ltd) for $8 \mathrm{~min}$. The membrane was washed with $1 \times$ PBST buffer twice, for 5 min each time, and then incubated at $4{ }^{\circ} \mathrm{C}$ overnight with skin milk containing the primary antibody (anti-His antibody, 4000:1). Then, the membrane was washed again, as described above, and incubated with skin milk containing the second antibody (anti-mouse antibody, 5000:1) for 45 min. Finally, the membrane was washed, as described above, and exposed to X-ray film. The bands were visualized using ECL Western Blotting Substrates (Promega Biotech Co., Ltd).

\section{Detection of apoptotic activity of VacA recombinant protein}

In a pilot experiment, we started with concentration $5 \mathrm{ug} / \mathrm{ml}$, gradually increased the protein concentration, incubated VacA protein with different concentrations and gradients and observed that cell morphological changes at each time point. It was found that apoptosis could be changed after the protein was incubated for a long time $(48 \mathrm{~h})$ with a low concentration $(5 \mathrm{ug} / \mathrm{ml})$ or stimulated for a short time $(24 \mathrm{~h})$ with a high concentration $(65 \mathrm{ug} / \mathrm{ml})$, and the effect of high concentration was more significant. Finally, we used a higher concentration $(65 \mathrm{ug} / \mathrm{ml})$ for further experiments to determine the apoptotic activity of VacA recombinant protein as described below.

\section{The morphological observation}


GES-1 cells were cultured in RPMI 1640 medium (HyClone; GE Healthcare Life Sciences) containing 10\% fetal bovine serum (Biological Industries Israel Beit-Haemek, Ltd) that was replaced daily, with trypsinization. Well-grown GES-1 cells were seeded into each well of a 6-well plate, containing $5 \times 10^{6}$ cells, and incubated with VacA recombinant protein (with a final concentration of $65 \mu \mathrm{g} / \mathrm{mL}$ in the experimental group) in an incubator at $37^{\circ} \mathrm{C}$ in an atmosphere of $5 \% \mathrm{CO}_{2}$ for $24 \mathrm{~h}$. At the same time, other batches of GES-1 cells were incubated with RPMI 1640 medium and incubated with isovolumetric protein buffers (buffer 7). These cells served as a blank control group and buffer control group. The plate was removed from the incubator at a later point. Cellular structural changes, including nuclear cytoplasmic apoptosis and cytoplasmic vacuolization, were visualized before incubation and after 6,12 and $24 \mathrm{~h}$ of incubation by invert microscopy. After incubation for $24 \mathrm{~h}$, a single cell suspension was prepared by trypsinization and the samples were made into pathological sections according to conventional methods and examined by transmission electron microscopy, as previously described [43].

\section{The terminal deoxynucleotidyl transferase-(TdT-) mediated dUTP nick end labeling (TUNEL) assay}

Analysis of apoptotic cells was performed using TUNEL assay kit (Beyotime Biotechnology, Shanghai, China) according to the manufacturer's instructions. GES-1 cells grown on glass coverslips in 6-well plates were treated with VacA recombinant protein (with a final concentration of $65 \mu \mathrm{g} / \mathrm{mL}$ in the experimental group) as described above, after incubation for $24 \mathrm{~h}$, cells were then washed with PBS, fixed with $4 \%$ paraformaldehyde in PBS at room temperature for $30 \mathrm{~min}$, and washed once with PBS. Then, cells were permeabilized in $0.5 \%$ Triton X-100 for 5 min and washed twice with PBS. The cells in each well were then incubated with $100 \mu \mathrm{L}$ of TUNEL reaction mixture containing TdT and Cyanine 3-dUTP at $37^{\circ} \mathrm{C}$ in the dark for $1 \mathrm{~h}$. After incubation, cells were washed three times with PBS and mounted in antifade mounting medium containing DAPI. The Cyanine 3-labeled TUNEL-positive cells were captured using a fluorescent microscopy at $400 \times$ magnification by using $550 \mathrm{~nm}$ excitation and $570 \mathrm{~nm}$ emission (red fluorescence). The nuclei were counterstained with DAPI, and the TUNEL-positive cells with red fluorescent staining, indicative of apoptosis. Cells from 20 images for each sample were counted and the percent of apoptotic cells was calculated by dividing the number of apoptotic cells by the number of total cells counted. All assays were performed in triplicate.

\section{Statistical analysis}

All the data were expressed as mean \pm standard deviation (SD) and the statistical analysis was performed using SPSS software (version 18.0; SPSS, Inc., Chicago, IL, USA). One-way analysis of variance (ANOVA), with Tukey-Kramer multiple comparison procedure, was used to determine the significance of differences among groups, Statistical significance was set at $P<0.05$.

\section{Abbreviations}

VacA: vacuolating cytotoxin A; TUNEL:The terminal deoxynucleotidyl transferase- (TdT-) mediated dUTP nick end labeling. 


\section{Declarations}

\section{Authors' contributions}

LZY wrote the manuscript; XS corrected the language; DT and SPZ analyzed and interpreted the data; ZMX analyzed the data and reviewed the paper; FW designed the study. All authors read and approved the final manuscript.

\section{Author details}

${ }^{1}$ Department of Gastroenterology, and ${ }^{2}$ Hunan Key Laboratory of Non-Resolving Inflammation and Cancer, The Third Xiangya Hospital, Central South University, Changsha, Hunan 410013, P.R. China.

\section{Acknowledgements}

Not applicable.

\section{Competing interests}

The authors declare that they have no competing interests.

\section{Availability of data and materials}

All data generated or analyzed during this study are included in this published article.

\section{Consent for publication}

Not applicable.

\section{Ethics approval}

This study was approved by the Xiangya Third Hospital Hospital Ethics Committee of Central South University (approval number 2019-S485).

\section{Funding}

The present study was supported by the National Natural Science Foundation of China (No. 81670509); the Independent Exploration and Innovation Project of Central South University (No. 2020zzts295) \the New Xiangya Talent Projects of the Third Xiangya Hospital of Central South University (no. 20180304); the National Key Research and Development Program of China (No. 2016YFC1201800); and the Planned Science and Technology Project of Hunan Province (No. 2016JC2051).

\section{References}

1. Noto JM, Peek RM Jr. Helicobacter pylori: an overview. Methods Mol Biol. 2012;921:7-10. 
2. Schistosomes liverflukes. and Helicobacter pylori. IARC Working Group on the Evaluation of Carcinogenic Risks to Humans. Lyon, 7-14 June 1994. IARC Monogr Eval Carcinog Risks Hum. 1994;61:1-241.

3. Palframan SL, Kwok T, Gabriel K. Vacuolating cytotoxin A (VacA), a key toxin for Helicobacter pylori pathogenesis. Front Cell Infect Microbiol. 2012;2:92.

4. Sun Y, Zhang J. Helicobacter pylori recrudescence and its influencing factors. J Cell Mol Med. 2019;23(12):7919-25.

5. Xia HH, Talley NJ. Apoptosis in gastric epithelium induced by Helicobacter pylori infection: implications in gastric carcinogenesis. Am J Gastroenterol. 2001;96(1):16-26.

6. Cover TL, Blanke SR. Helicobacter pylori VacA, a paradigm for toxin multifunctionality. Nat Rev Microbiol. 2005;3(4):320-32.

7. Mcclain MS, Beckett AC, Cover TL. Helicobacter pylori Vacuolating Toxin and Gastric Cancer. Toxins (Basel).2017;9(10).

8. Cover TL, Blaser MJ. Purification and characterization of the vacuolating toxin from Helicobacter pylori. J Biol Chem. 1992;267(15):10570-5.

9. Junaid M, Al-Gubare S, Yousef M, Ubol MN, Leetachewa S, Muanprasat C, Angsuthanasombat C, Chaicumpa W, Ali N, Katzenmeier G. Sequence and apoptotic activity of VacA cytotoxin cloned from a Helicobacter pylori Thai clinical isolate. Biomed Res Int. 2014;2014:398350.

10. González-Rivera C, Gangwer KA, McClain MS, Eli IM, Chambers MG, Ohi MD, Lacy DB, Cover TL. Reconstitution of Helicobacter pylori VacA toxin from purified components. Biochemistry. 2010;49(27):5743-52.

11. de Bernard M, Papini E, de Filippis V, Gottardi E, Telford J, Manetti R, Fontana A, Rappuoli R, Montecucco $\mathrm{C}$. Low pH activates the vacuolating toxin of Helicobacter pylori, which becomes acid and pepsin resistant. J Biol Chem. 1995;270(41):23937-40.

12. Cover TL, Hanson PI, Heuser JE. Acid-induced dissociation of VacA, the Helicobacter pylori vacuolating cytotoxin, reveals its pattern of assembly. J Cell Biol. 1997;138(4):759-69.

13. Wang F, Pan J, Luo L, Huang L, Lu H, Guo Q, Xu C, Shen S. Chronic Helicobacter pylori infection induces the proliferation and apoptosis in gastric epithelial cells and gastric precancerosis in Mongolian gerbils. Zhong Nan Da Xue Xue Bao Yi Xue Ban. 2011 Sep;36(9):865-71.

14. de Bernard M, Arico B, Papini E, Rizzuto R, Grandi G, Rappuoli R, Montecucco C. Helicobacter pylori toxin VacA induces vacuole formation by acting in the cell cytosol. Mol Microbiol. 1997;26(4):66574.

15. Yahiro K, Hirayama T, Moss J, Noda M. New Insights into VacA Intoxication Mediated through Its Cell Surface Receptors. Toxins (Basel).2016;8(5).

16. Garner JA, Cover TL. Binding and internalization of the Helicobacter pylori vacuolating cytotoxin by epithelial cells. Infect Immun. 1996;64(10):4197-203. 
17. Patel HK, Willhite DC, Patel RM, Ye D, Williams CL, Torres EM, Marty KB, MacDonald RA, Blanke SR. Plasma membrane cholesterol modulates cellular vacuolation induced by the Helicobacter pylori vacuolating cytotoxin. Infect Immun. 2002;70(8):4112-23.

18. Chang H, Chen D, Ni B, Zuo Q, Wang C, Han R, Lan C. Cortactin Mediates Apoptosis of Gastric Epithelial Cells Induced by VacA Protein of Helicobacter pylori. Dig Dis Sci. 2016;61(1):80-90.

19. Belyĭ luF, Sheklakova LA, Vakhrameeva MS, ZhukhovitskiI VG, Petrukhin VG, Belaia luA. Production of recombinant fragment of VacA protein and development of non-invasive method for the diagnosis of Helicobacter pylori infection. Mol Gen Mikrobiol Virusol.2005;(1):32-35.

20. Yan J, Mao YF. Construction of a prokaryotic expression system of vacA gene and detection of vacA gene, VacA protein in Helicobacter pylori isolates and ant-VacA antibody in patients' sera. World $\mathrm{J}$ Gastroenterol. 2004;10(7):985-90.

21. Hasanzadeh L, Ghaznavi-Rad E, Soufian S, Farjadi V, Abtahi H. Expression and Antigenic Evaluation of VacA Antigenic Fragment of Helicobacter Pylori. Iran J Basic Med Sci. 2013;16(7):835-40.

22. Papini E, Zoratti M, Cover TL. In search of the Helicobacter pylori VacA mechanism of action. Toxicon. 2001;39(11):1757-67.

23. Sewald X, Fischer W, Haas R. Sticky socks: Helicobacter pylori VacA takes shape. Trends Microbiol. 2008;16(3):89-92.

24. Chang $\mathrm{H}$, Zuo Q, Jing $\mathrm{H}$. Isolation and purification of recombinant VacA and Helicobacter pylorisecreted VacA and VacA-induced cell vacuolar change and apoptosis. Military Medical Sciences.2014;(9):714-718, 744.

25. Roesler BM, Rabelo-Goncalves EM, Zeitune JM. Virulence Factors of Helicobacter pylori: A Review. Clin Med Insights Gastroenterol. 2014;7:9-17.

26. Rhead JL, Letley DP, Mohammadi M, Hussein N, Mohagheghi MA, Eshagh Hosseini M, Atherton JC. A new Helicobacter pylori vacuolating cytotoxin determinant, the intermediate region, is associated with gastric cancer. Gastroenterology. 2007;133(3):926-36.

27. Cho SJ, Kang NS, Park SY, Kim BO, Rhee DK, Pyo S. Induction of apoptosis and expression of apoptosis related genes in human epithelial carcinoma cells by Helicobacter pylori VacA toxin. Toxicon.2003;42(6):601-611.

28. Manetti R, Massari P, Burroni D, de Bernard M, Marchini A, Olivieri R, Papini E, Montecucco C, Rappuoli R, Telford JL. Helicobacter pylori cytotoxin: importance of native conformation for induction of neutralizing antibodies. Infect Immun. 1995;63(11):4476-80.

29. Nakamura T, Koma D, Oshima M, Hoshino H, Ohmoto T, Uegaki K. Application of chromosomal gene insertion into Escherichia coli for expression of recombinant proteins. J Biosci Bioeng. 2018;126(2):266-72.

30. Singh SM, Panda AK. Solubilization and refolding of bacterial inclusion body proteins. J Biosci Bioeng. 2005;99(4):303-10.

31. Mcclain MS, Cover TL. Expression of Helicobacter pylori vacuolating toxin in Escherichia coli. Infect Immun. 2003;71(4):2266-71. 
32. Ki MR, Hong IH, Park JK, Hong KS, Hwang OK, Han JY, Ji AR, Park SI, Lee SK, Yoo SE, Jeong KS. Potent neutralization of vacuolating cytotoxin (VacA) of Helicobacter pylori by immunoglobulins against the soluble recombinant VacA. Anticancer Res. 2009;29(6):2393-402.

33. Shu XL, Xu H, Yu TT, Zhong JX, Lei T. Regulation of apoptosis in human gastric cancer cell line SGC7901 by L-arginine. Panminerva Med. 2014;56(3):227-31.

34. Czajkowsky DM, Iwamoto H, Cover TL, Shao Z. The vacuolating toxin from Helicobacter pylori forms hexameric pores in lipid bilayers at low pH. Proc Natl Acad Sci U S A. 1999;96(5):2001-6.

35. McGowan CC, Necheva AS, Forsyth MH, Cover TL, Blaser MJ. Promoter analysis of Helicobacter pylori genes with enhanced expression at low pH. Mol Microbiol. 2003;48(5):1225-39.

36. Ricci V, Sommi P, Fiocca R, Necchi V, Romano M, Solcia E. Extracellular pH modulates Helicobacter pylori-induced vacuolation and VacA toxin internalization in human gastric epithelial cells. Biochem Biophys Res Commun. 2002;292(1):167-74.

37. Ling SS, Khoo LH, Hwang LA, Yeoh KG, Ho B. Instrumental Role of Helicobacter pylori Y-Glutamyl Transpeptidase in VacA-Dependent Vacuolation in Gastric Epithelial Cells. PLOS ONE. 2015;10(6):e131460.

38. Czajkowsky DM, Iwamoto H, Szabo G, Cover TL, Shao Z. Mimicry of a Host Anion Channel by a Helicobacter pylori Pore-Forming Toxin. Biophys J. 2005;89(5):3093-101.

39. de Bernard M, Arico B, Papini E, Rizzuto R, Grandi G, Rappuoli R, Montecucco C. Helicobacter pylori toxin VacA induces vacuole formation by acting in the cell cytosol. Mol Microbiol. 1997;26(4):66574.

40. Cho SJ, Kang NS, Park SY, Kim BO, Rhee DK, Pyo S. Induction of apoptosis and expression of apoptosis related genes in human epithelial carcinoma cells by Helicobacter pylori VacA toxin. Toxicon.2003;42(6):601-611.

41. Gebert B. Helicobacter pylori Vacuolating Cytotoxin Inhibits T Lymphocyte Activation. Science. 2003;301(5636):1099-102.

42. Green MR, Sambrook J. (2012) Molecular Cloning: A Laboratory Manual. 4th edition. Cold Spring Harbor, NY, USA: Cold Spring Harbor Laboratory Press.

43. Winey M, Meehl JB, O'Toole ET, Giddings TH Jr. Conventional transmission electron microscopy. Mol Biol Cell. 2014;25(3):319-23.

\section{Figures}


a

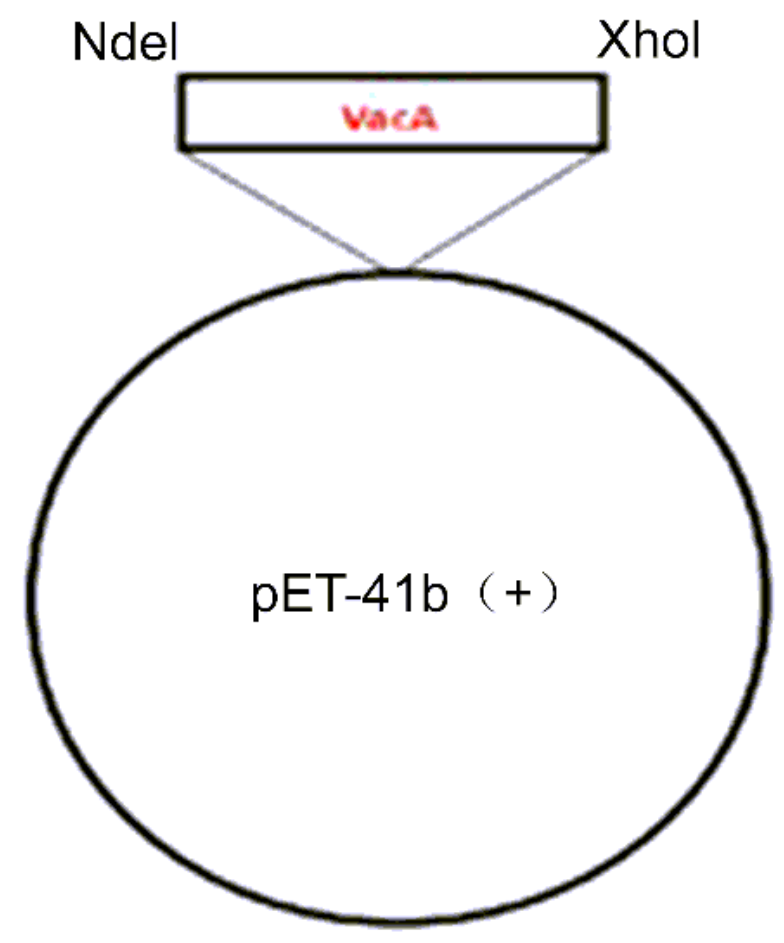

C
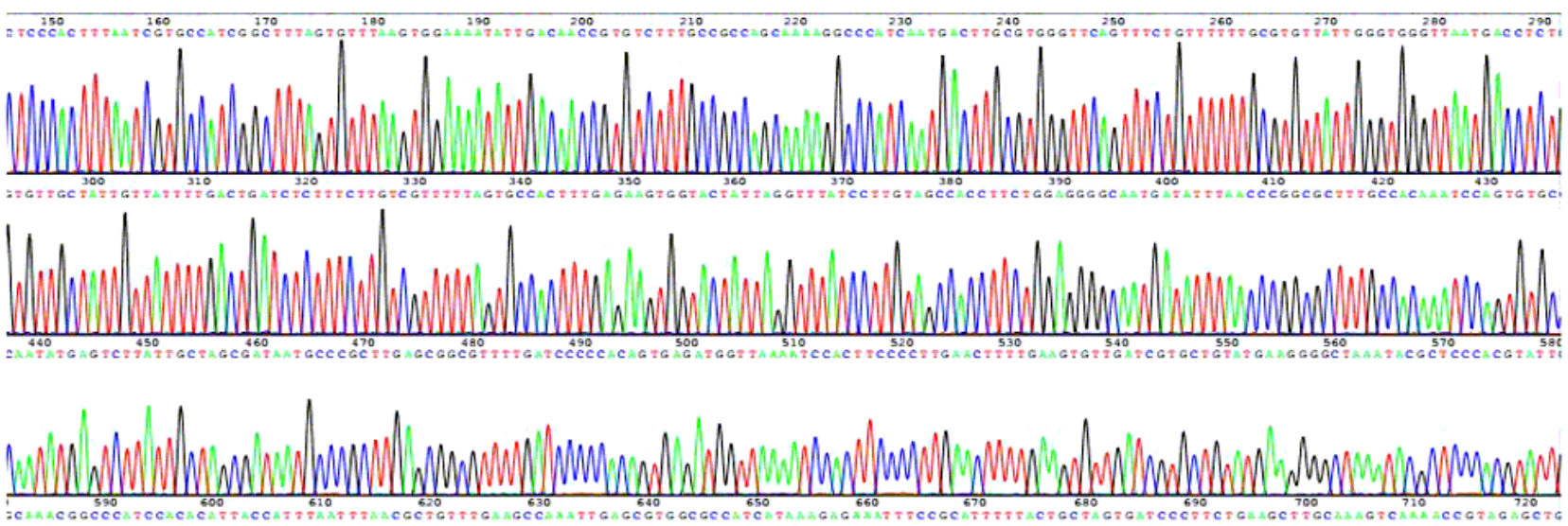

\section{VacA fragment $\rightarrow$}

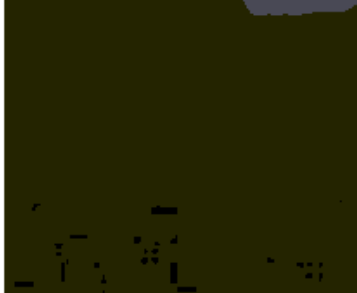

10000 8000 6000 5000 4000 3000 2000 1000

000

1000

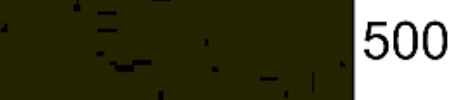



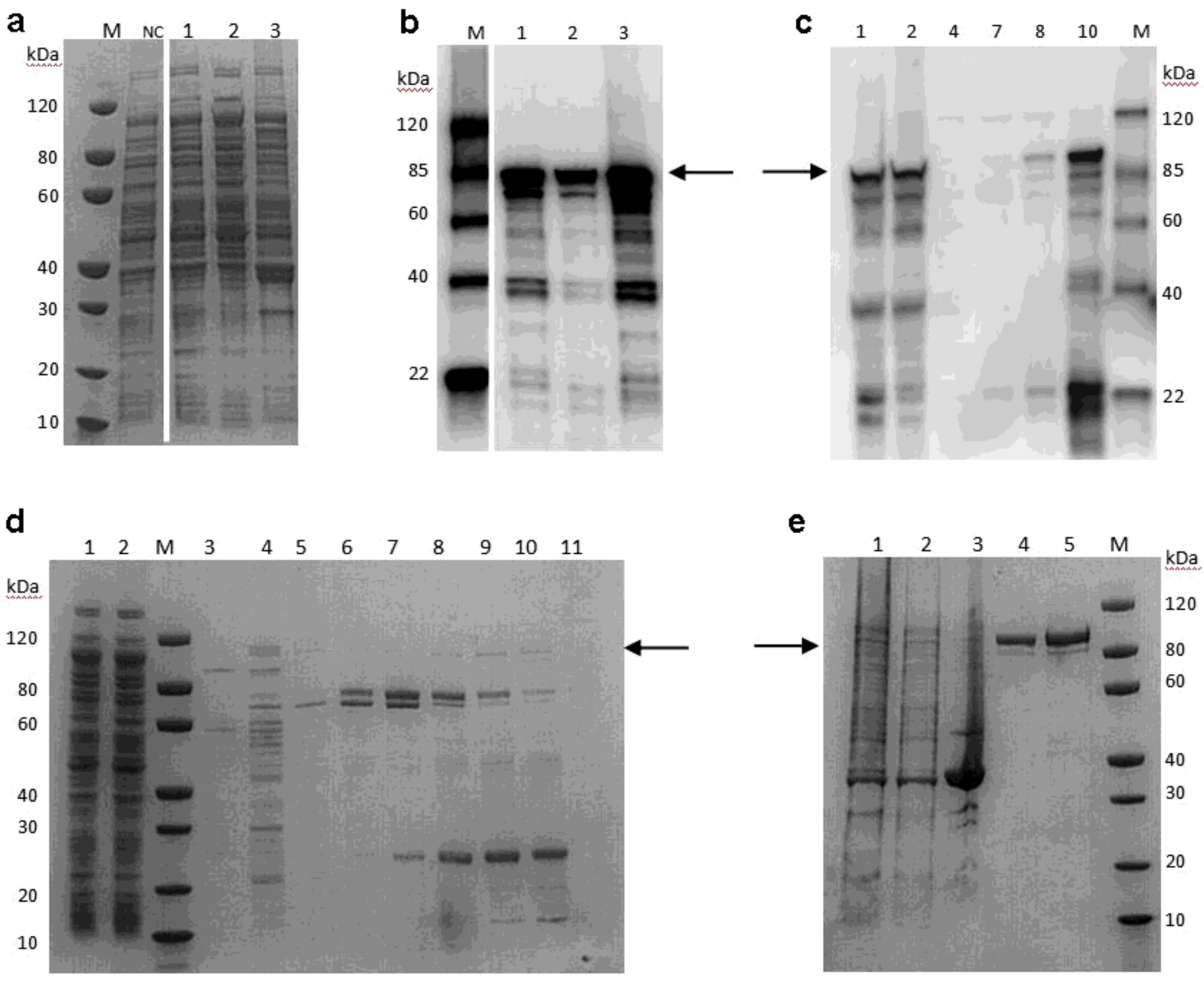

\section{Figure 2}

Expression and purification of the VacA recombinant protein in the pET-41b-vacA34-854- E. coli BL21(DE3) system. $a$ and $b$ : The expression of the VacA recombinant protein in E. coli BL21(DE3) cells as detected by SDS-PAGE and western blotting, respectively. NC: no induced cell lysis; Lane $1: 15^{\circ} \mathrm{C}$ in the induction of cell lysis of $16 \mathrm{~h}$; and Lane $2: 15^{\circ} \mathrm{C}$ in the induction of $16 \mathrm{~h}$ of cell lysis supernatant; Lane 3 : $15^{\circ} \mathrm{C}$ in precipitation of cell lysis induced $16 \mathrm{~h}$. $\mathrm{c}$ and d: VacA recombinant protein in the supernatant purified with Ni column (NTA) as detected by western blotting and SDS-PAGE, respectively. The column equilibration buffer consists of $50 \mathrm{mM}$ Tris- $\mathrm{HCl}, 150 \mathrm{mM} \mathrm{NaCl}, \mathrm{pH}$ 8.0, and wash buffer consists of 50 $\mathrm{mM}$ Tris- $\mathrm{HCl}, 1 \%$ Triton- $\mathrm{X} 114,8 \mathrm{M}$ urea, $150 \mathrm{mM} \mathrm{Nacl}$, PH 8.0). The target protein was eluted using a stepwise gradient of imidazole (i.e. 20,50, 100 and $500 \mathrm{mM}$ ) and the results are shown as below: Lane 1: the supernatant after cell lysate centrifugation; Lane 2: outflow; Lanes 3-5: $20 \mathrm{mM}$ imidazole; Lanes 6-7: 50 mM imidazole. Lanes 8-9: 100 mM imidazole; Lane 10-11; 500 mM imidazole. e: VacA recombinant protein in the inclusion bodies purified with Ni column (IDA) as detected by SDS-PAGE analysis. Channel 
2: outflow; Lane 3: precipitation of cell lysate after centrifugation; Lane 4: $50 \mathrm{mM}$ Tris-HCl, $20 \mathrm{mM}$ imidazole, $8 \mathrm{M}$ urea, $\mathrm{PH} 8.0$ elution; Lane 5: wash with $50 \mathrm{mM}$ Tris- $\mathrm{HCl}, 300 \mathrm{mM}$ imidazole, $8 \mathrm{M}$ urea, $\mathrm{PH}$ 8.0

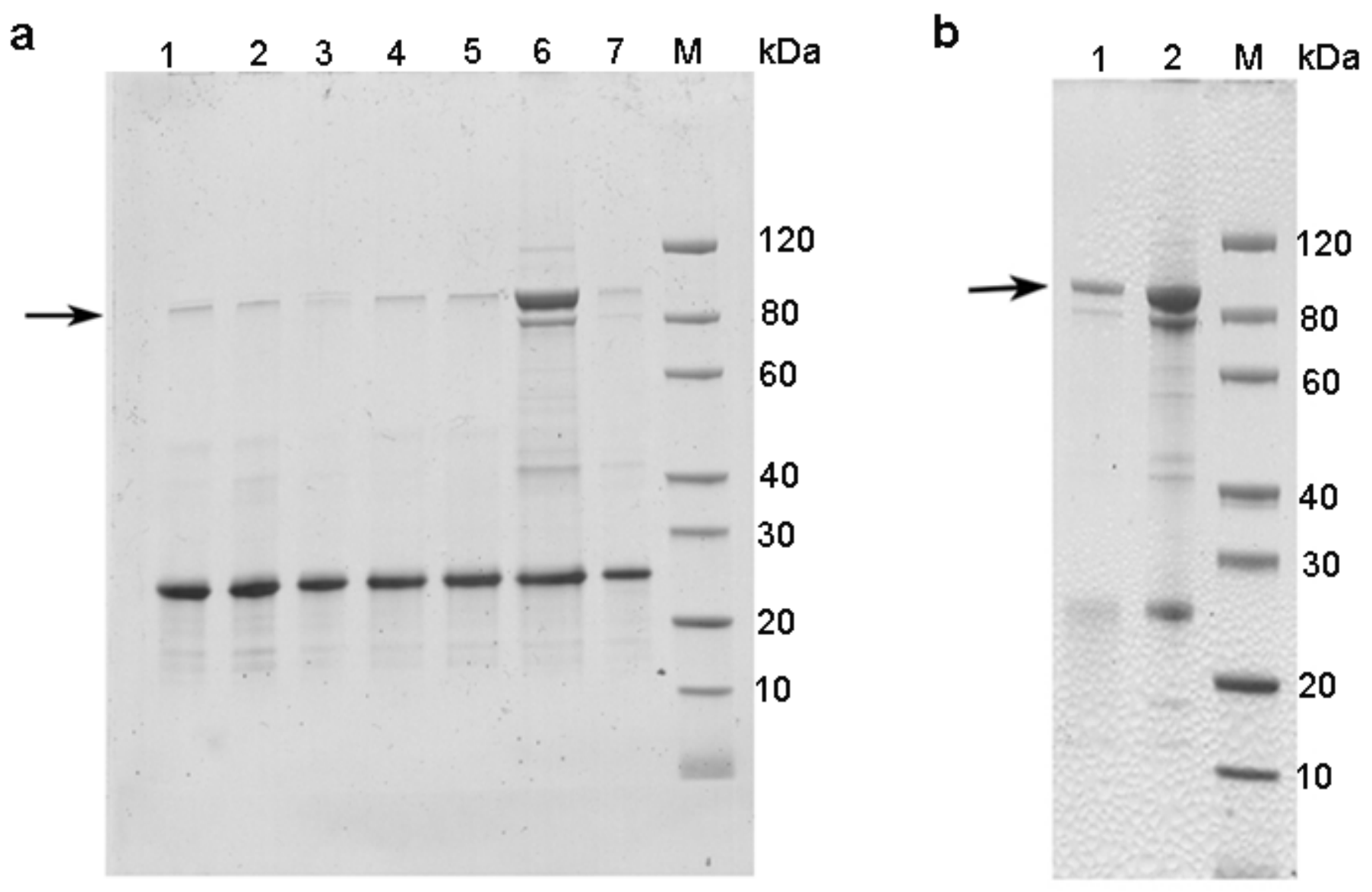

\section{Figure 3}

Renaturation of the target recombinant protein by various buffers as detected by sodium dodecyl sulfate polyacrylamide gel electrophoresis. a. Lane 1: buffer 1 (50 mM Tris,10\% Gly, $150 \mathrm{mM} \mathrm{NaCl}, \mathrm{pH}$ 8); Lane 2: buffer 2 ( $50 \mathrm{mM}$ Tris, $10 \%$ Gly, $150 \mathrm{mM} \mathrm{NaCl}, 0.1 \mathrm{mM}$ DL-dithiothreitol (DTT), pH 8.0); Lane 3: buffer 3 (1 × phosphate buffered saline (PBS), pH 7.4; Lane 4: buffer 4 (1 × PBS, 10\% GLy, $500 \mathrm{mM} \mathrm{NaCl}, \mathrm{pH} 7.4)$; Lane 5: buffer 5 ( $1 \times$ PBS, $10 \%$ GLy, $500 \mathrm{mM} \mathrm{NaCl}, 0.1 \mathrm{mM} \mathrm{DTT}$, pH 7.4); Lane 6: buffer 6 (20 mM Tris, $2 \mathrm{M}$ urea, $400 \mathrm{mM}$ Arg, $2.5 \mathrm{mM}$ cysteamine, $0.25 \mathrm{mM}$ cystamine, $\mathrm{pH}$ 8.5); and Lane 7: buffer 7 (50 mM acetic acid, pH2.9). b. Lane 1: buffer 6 (20 mM Tris, $2 \mathrm{M}$ urea, $400 \mathrm{mM}$ Arg, $2.5 \mathrm{mM}$ cysteamine, $0.25 \mathrm{mM}$ cystamine, pH 8.5); and Lane 2: buffer 7 (50 mM acetic acid, pH 2.9) 
a

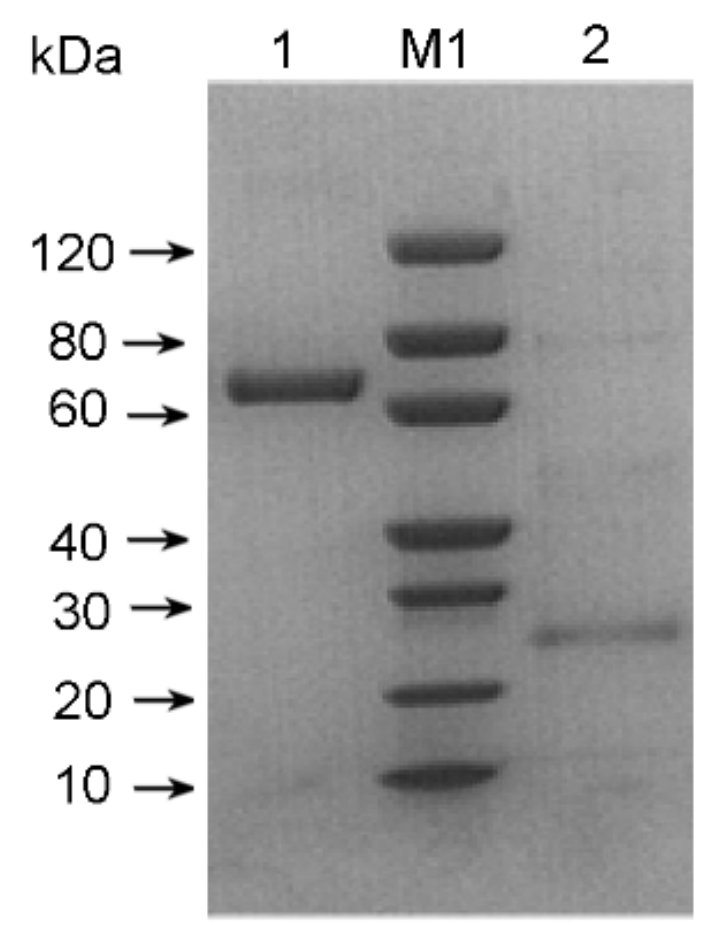

C

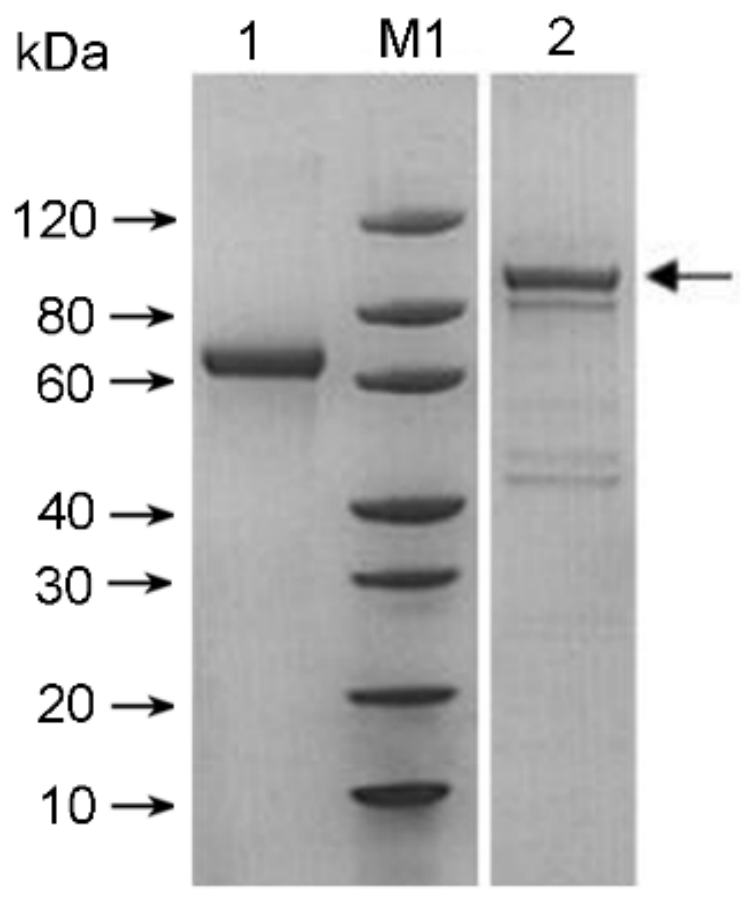

b
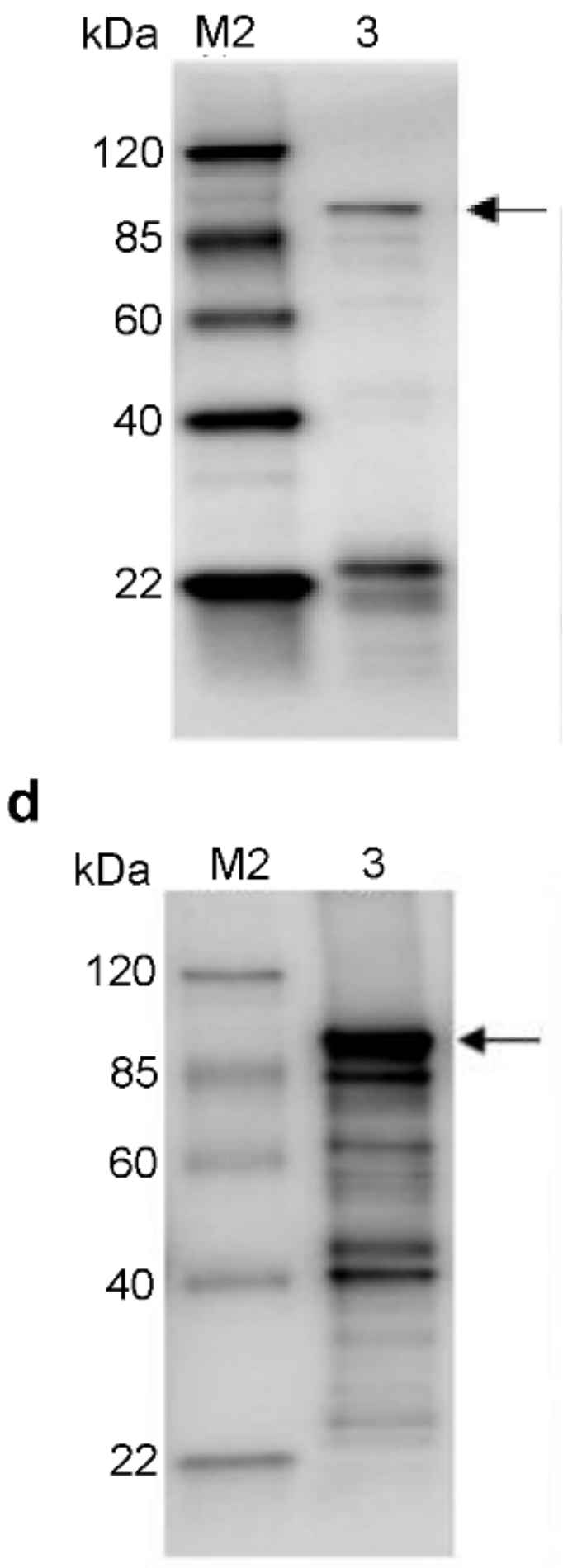

\section{Figure 4}

Expression of VacA recombinant protein in the supernatant and pellet as detected by sodium dodecyl sulfate polyacrylamide gel electrophoresis and western blotting. a and b. Expression of VacA recombinant protein in the supernatant as detected by SDS-PAGE (left) and western blotting (right); $c$ and d. Expression of VacA recombinant protein in the pellet as detected by SDS-PAGE (left) and western 
blotting (right). Lane 1: BSA $(2.00 \mu \mathrm{g})$; Lane 2: VacA34-854 $(2.00 \mu \mathrm{g})$; Lane 3: VacA34-854. Both M1 and M2 are protein markers. BSA,bovine serum albumin
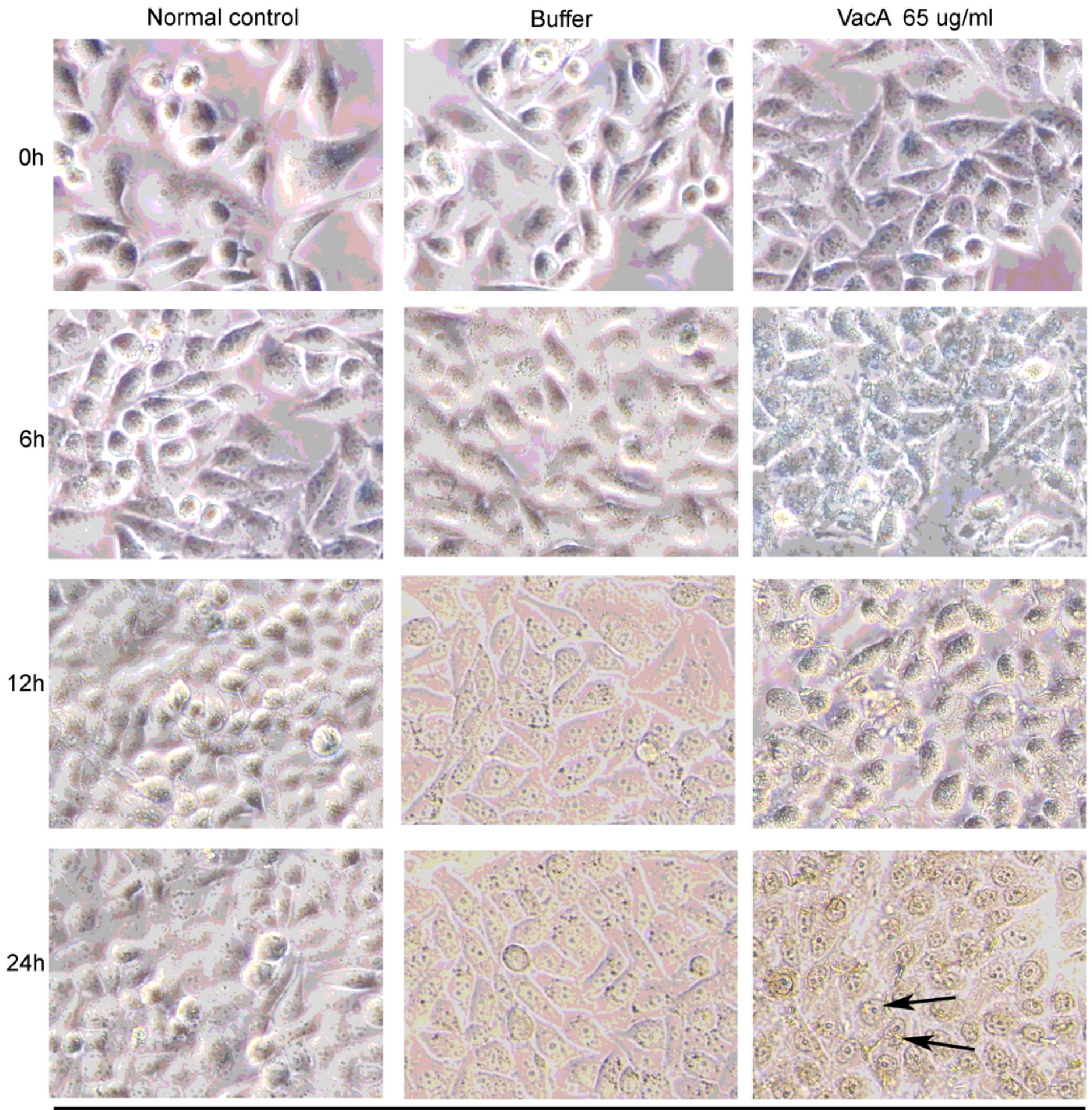

\section{GES-1}

\section{Figure 5}

Morphological changes of GES-1 cells as observed by inverted microscopy after incubation with a high final concentration $(65 \mu \mathrm{g} / \mathrm{mL})$ of VacA recombinant protein for $24 \mathrm{~h}$. Cellular morphological changes were visualized before incubation $(0 \mathrm{~h})$ and 6,12 and $24 \mathrm{~h}$ after incubation by invert microscopy 
(Magnification $\times 100$ ). After $24 \mathrm{~h}$ stimulation of VacA recombinant protein (as indicated by the arrow), significant cell morphological changes evident of apoptosis including early nuclear immobilization and clustering in GES-1 cells were observed. A large number of nuclei were retracted and chromatin in the nucleus converged to the edge

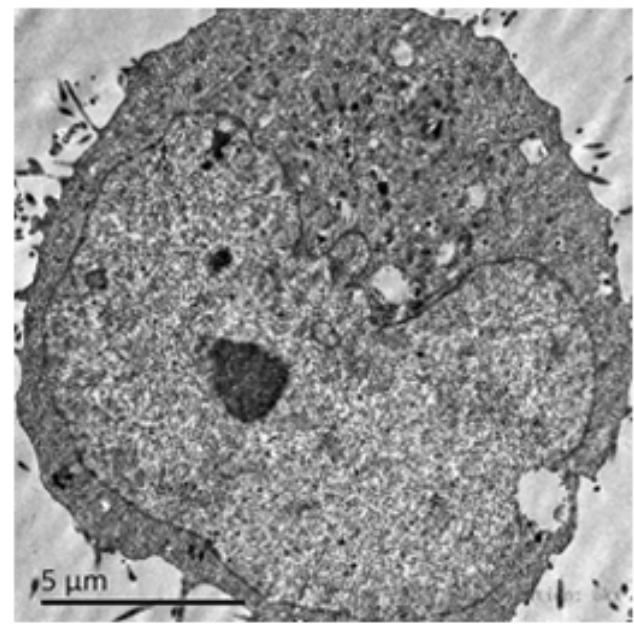

a

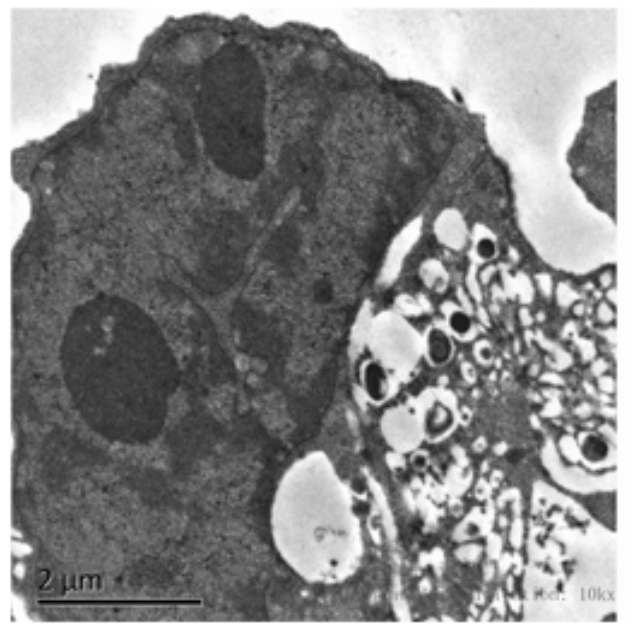

C2

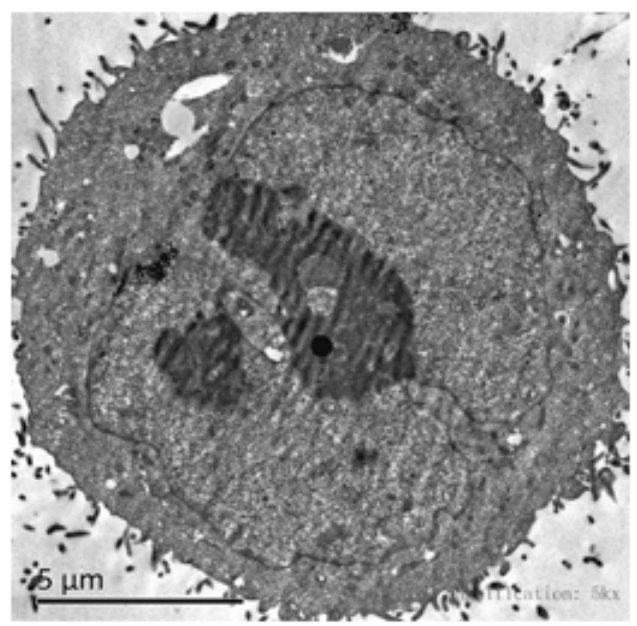

b

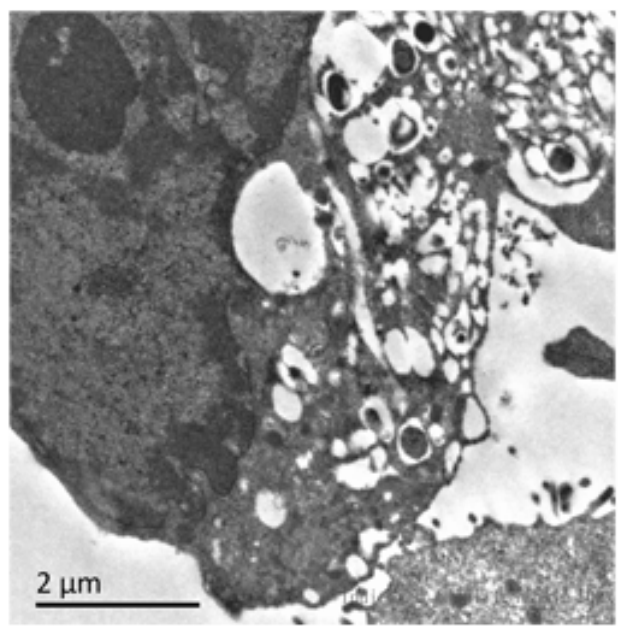

c3

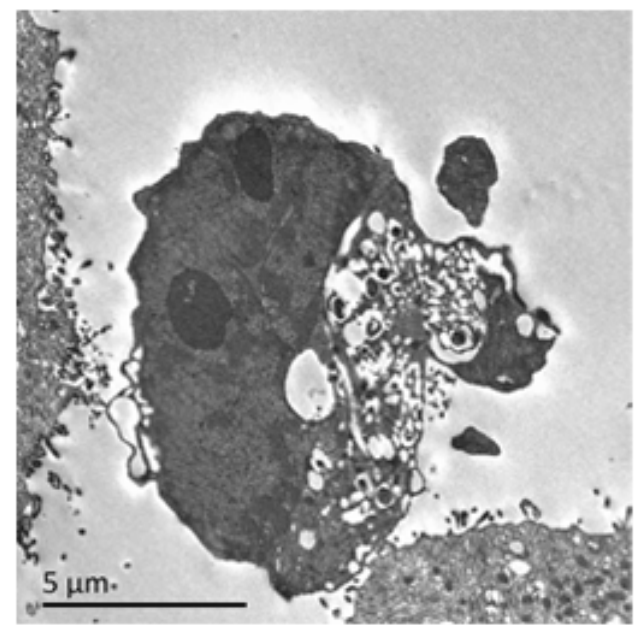

C1

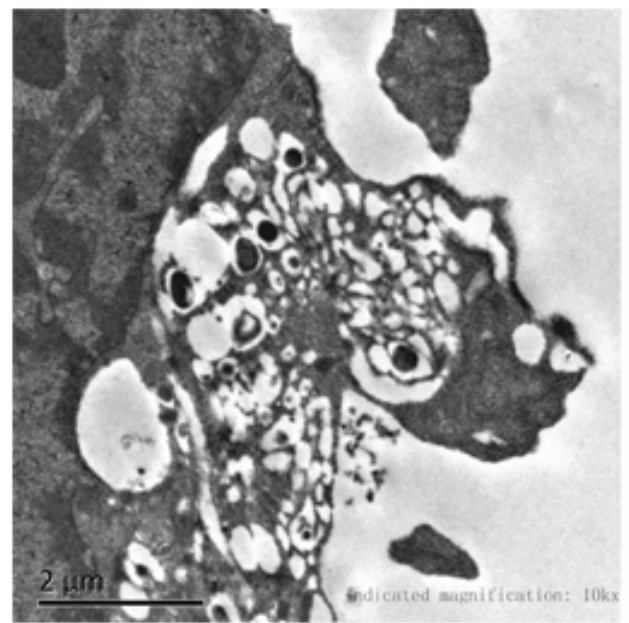

C4

\section{Figure 6}

Morphological changes of GES-1 cells as demonstrated by the observed by transmission electron microscopy after incubation at a high final concentration $(65 \mu \mathrm{g} / \mathrm{mL})$ of VacA recombinant protein for 24 h. a: The blank control (Magnification ×5,000). b: The buffer control (50 mM acetic acid, $\mathrm{pH} 2.9$, Magnification $\times 5,000$ ). C: VacA recombinant protein (at a final concentration of $65 \mu \mathrm{g} / \mathrm{mL}$ ); c1: The cell volume is reduced and the surface microvilli disappears (Magnification $\times 5,000$ ); c2: Nucleus shrinks and agglutinates to the periphery (Magnification $\times 10,000$ ); and c3 \& c4: Cytoplasmic disintegration and vacuoles (Magnification $\times 10,000$ ) 
a
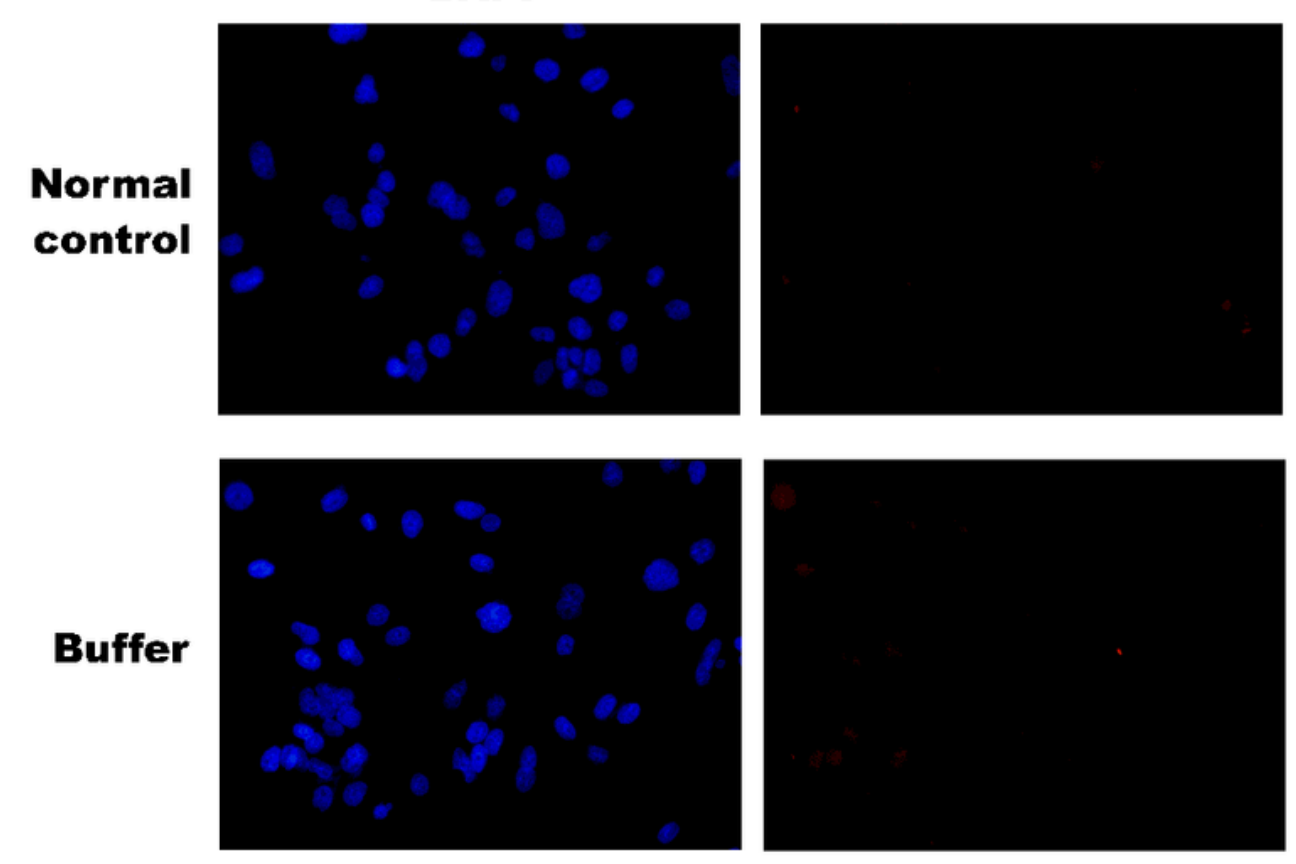

Buffer
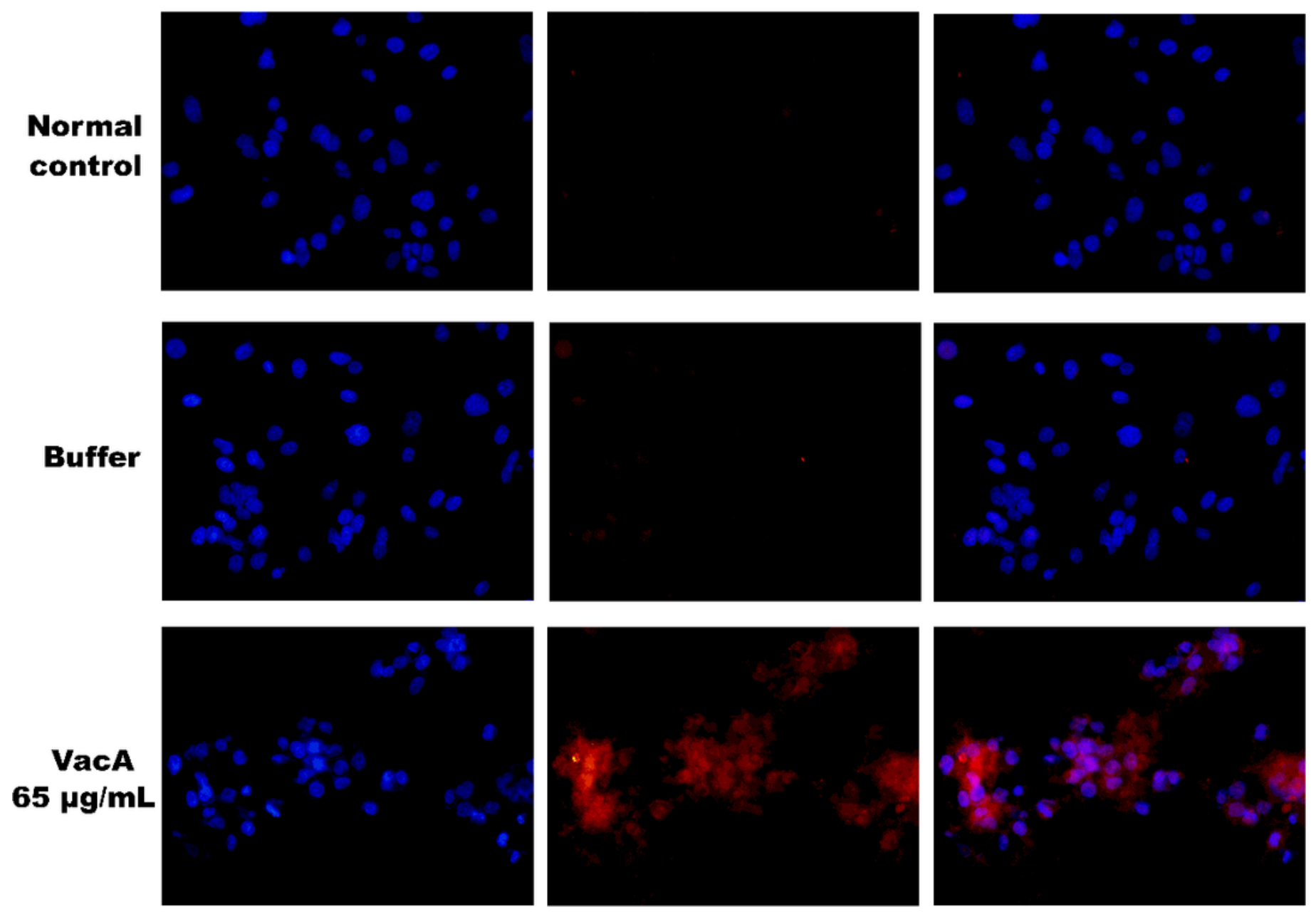

b

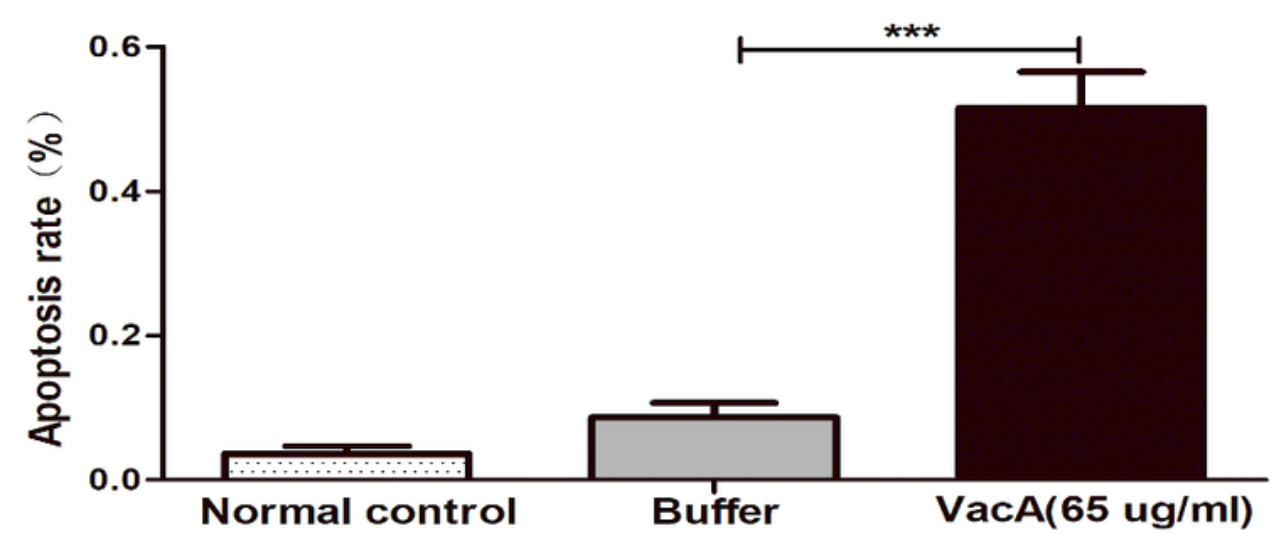

Figure 7

Detection of cells apoptosis induced by VacA recombinant protein using TUNEL assay. VacA recombinant protein induced GES-1 cell apoptosis. GES-1 cells treated with VacA recombinant protein at a high concentration (at a final $65 \mu \mathrm{g} / \mathrm{mL}$ ) for $24 \mathrm{~h}$. a: Representative images of the TUNEL assay (Magnification $\times 400$ ). Nuclei were counterstained with DAPI (blue) and TUNEL-positive cells (red) indicate 
apoptosis. b: Quantification of results. Results are presented as the mean \pm standard deviation, $\star \star \star: ~ P<$ 0.001 vs. the buffer control group

\section{Supplementary Files}

This is a list of supplementary files associated with this preprint. Click to download.

- SupplementaryFig.S1.docx 